\title{
FUNDAMENTALS OF MEDICAL PREVENTION IN PRACTICE OF A FAMILY DOCTOR
}

\section{A.S. Biduchak, M.I. Gritsyuk, T.I. Domanchuk}

HSEE of Ukraine "Bukovinian State Medical University", Chernivtsi

\begin{abstract}
The article analyzes in detail the definitions of the concepts of "prophylaxis», "disease prevention», "types of prevention» and specifies the priority of prevention in the field of the public health as the main principle of health protection of the citizens of Ukraine. The application of this knowledge in practice seems to be one of the key points contributing to the implementation of the public health policy in the field of health strengthening. This implies both increasing of the knowledge level of specialists in this field, and the skills of using this knowledge in practice, in particular, to increase patient awareness in the field of combating risk factors for the chronic noncommunicable diseases'occurrence.
\end{abstract}

\section{Key words:}

medical prevention, levels of prevention, types of prevention, family medicine, quality criteria for prevention, healthy lifestyle.

\section{Clinical and} experimental pathology. 2020. Vol.19, №1

(71). P.133-138.

DOI:10.24061/1727-4338. XIX.1.71.2020.324

\section{ОСНОВИ МЕДИЧНОЇ ПРОФІЛАКТИКИ У ПРАКТИЦІ СІМЕЙНОГО ЛІКАРЯ}

\section{А.С. Бідучак М.І. Грицюк, Т.І. Доманчук}

Резюме. У статті докладно проаналізовано визначення поняттям «профілактика», «профілактика захворювань», «види профілактики» $i$ конкретизований пріоритет профілактики у сфері охорони здоров'я як основний принцип охорони здоров'я громадян України. Застосування ичих знань у практичній діяльності представлясться одним з ключових моментів, щзо сприяють реалізації політики системи охорони здоров'я у сфері зміцнення громадського здоров'я. Це передбачає як підвищення рівня знань фахівців у иій сфері, так і навички використання цчих знань на практиці, зокрема для підвищення рівня інформованості пацієнтів в області боротьби з факторами ризику виникнення хронічних неінфекиійних захворювань.

\section{ОСНОВЫ МЕДИЦИНСКОЙ ПРОФИЛАКТИКИ В ПРАКТИКЕ СЕМЕЙНОГО} ДОКТОРА

\section{А.С. Бидучак М.И. Грицюк, Т.И. Доманчук}

Резюме. В статье подробно проанализировано определения понятий «профилактика», «профилактика заболеваний», «виды профилактики» и конкретизирован приоритет профилактики в сфере охрань здоровья как основной принии охраны здоровья граждан Украины. Применения этих знаний 6 практической деятельности представляется одним из ключевых моментов, способствующих реализации политики системь здравоохранения в сфере укрепления общественного здоровья. Это предполагает как повышение уровня знаний специалистов в данной сфере, так и навыки использования этих знаний на практике, в частности для повышения уровня информированности пациентов в области борьбы с факторами риска возникновения хронических неинфекционных заболеваний.

The specific content of the prevention concept has many meanings, used to denote different directions of policy, social, collective and individual activity and several types of medical activity. Nevertheless, the specific objective content of this concept is always action - the ability to promote or impede the implementation of one or another public health trend that interests us.

Thus, the general content of the «prevention» concept can be reduced to activities by which it is possible to maintain and improve individual, group or public health. We can say that this is a set of measures aimed at preventing people from diseases' development, their exacerbations, socio-psychological and personal maladaptation $[3,8,12,18,25]$.

Disease prevention is a system of medical and nonКлінічна та експериментальна патологія. 2020. Т.19, №1(71) medical measures aimed at preventing, reducing the risk of developing deviations in the state of health and disease, preventing or slowing their progression, and reducing their adverse effects.

Medical prophylaxis is a system of preventive measures implemented through the healthcare system.

Prevention is a system of state, social, hygienic and medical measures aimed at ensuring a high level of health and preventing disease.

Preventive measures will only be effective if they are carried out at all levels: state, labor collective, family, individual.

The state level of prevention is ensured by the measures to improve the population' living and cultural standards, legislative measures regulating the protection 
of public health, the participation of all ministries and departments, public organizations in creating optimal living conditions from the standpoint of health through the full use of the scientific and technological progress achievement.

Preventive measures on the level of the labor collective include measures to ensure sanitary and hygienic control of production conditions, hygiene of the home, trade and public catering, creation of a rational conditions of work, rest, a favorable psychological climate and relationships in the team, and sanitary-hygienic education.

Prevention in the family is inseparably linked with individual prevention and is a determining condition for the formation of a healthy lifestyle, it is designed to provide a high hygienic level of housing, a balanced diet, good rest, physical education and sports, creating conditions that exclude the appearance of bad habits.

Medical prophylaxis in relation to the population is defined as:

1) individual - preventive measures, carried out with individual persons. Individual medical prophylaxis - personal hygiene - scientific and practical medical activity for the study, development and implementation in everyday individual life of hygienic knowledge, requirements and principles of maintaining and strengthening health. This concept is also used to determine the conformity of the human life to medical and hygienic standards and medical recommendations conscious active hygienic behavior;

2) group - preventive measures carried out, in groups of people with similar symptoms and risk factors (target groups);

3) population (mass) - preventive measures, covering large groups of the population (population) or the entire population as a whole. The population level of prevention, as a rule, is not limited to medical measures - these are local prevention programs or mass campaigns aimed at improving health and preventing diseases.

However, the medical-ecological systematicity emphasizes the convention of dividing prevention into socio-economic and medical measures and into social and individual ones. All of its numerous components are interconnected by social relations and are revealed in the public health policy $[1,7,11,14,20]$.

State medical prophylaxis, preventive (protective, social, public) medicine is the scientific and practical medical activity to study the prevalence of diseases, disabilities, causes of death in society in order to justify socio-economic, legal, administrative, hygienic and other areas and preventive measures, medical events.

Reasons requiring enhanced prevention at the present stage:

1) the type of pathology changes: from epidemic (infection) to non-epidemic;

2) an adverse clinical course of viral pathology is noted;

3) unfavorable trends in the dynamics of demographic processes;

4) the physical and neuropsychic health of the population is deteriorating (especially children's);

5) increased environmental aggressivenes.

In preventive medicine, the idea of the prevention

ISSN 1727-4338 https://www.bsmu.edu.ua stages is introduced, which is based on modern epidemiological views on the causality of human diseases. The subjects of the application of preventive measures and impacts are the different stages of the disease development, including various preclinical conditions, and the objects are individuals, groups of individuals, individual populations and the population as a whole $[2,6,10,15]$.

In those cases where preventive measures are aimed at eliminating the cause (original cause, etiological factor, disease etiology) and/or weakening of the action of pathogenetic risk factors for the development of the incidence that has not yet occurred (the chain of epidemiological causes of the disease), the question is about primary prevention. In modern epidemiology, primary prophylaxis is divided into preexposure prophylaxis and primary specific $[1,4,11,13,21]$.

Preexposure prophylaxis is a set of measures aimed at preventing risk factors for the occurrence of diseases associated with unfavorable conditions of life, the environment and working conditions, mode of life.

Primary prevention is a complex of medical and nonmedical measures aimed at preventing the development of deviations in the state of health and diseases, eliminating their causes common to the entire population, its individual groups and individuals.

The purpose of primary prevention is to reduce the frequency of new cases (incidence) of a disease by controlling its causes, epidemiological conditions, and risk factors.

\section{Primary prevention includes:}

1. Conducting environmental and sanitary-hygienic screening and taking measures to reduce the influence of harmful factors on the human body (improving the quality of atmospheric air, drinking water, the structure and quality of nutrition, working conditions, everyday life and rest, the level of psychosocial stress and other factors affecting the quality of life).

2. The formation of the healthy mode of life, including:

-the creation of a permanent information and propaganda system aimed at increasing the level of knowledge of all categories of the population about the influence of negative factors and the possibilities of reducing it;

-hygienic education;

-lowering in the spread of smoking and tobacco consumption, reduction in alcohol consumption, prevention of the drug addiction;

-attracting the population to the physical education, tourism and sports, increasing the availability of these types of rehabilitation.

3. Measures to prevent the development of somatic and mental diseases and injuries, including professionally caused, accidents, disability and mortality from unnatural causes, road accident injuries, etc.

4. The implementation of medical screening in order to reduce the impact of risk factors and early detection and prevention of diseases of various target populations by conducting preventive medical examinations:

-preliminary - when applying for a job or entering an educational institution;

Клінічна та експериментальна патологія. 2020. Т.19, №1(71) 
-at registration and conscription;

-recurrent - for giving employment control, associated with exposure to harmful and dangerous production factors, or with increased danger to others;

-examinations of decreed contingents (catering, trade, children's institutions, etc.) in order to prevent the spread of a number of diseases.

5. Immunoprophylaxis of various population groups.

6. Clinical examination of the population in order to identify the risks of developing chronic somatic diseases and the improvement of individuals and contingents under the influence of adverse factors, using medical and non-medical measures.

\section{Basic principles of primary prevention:}

1) the continuity of preventive measures (throughout life, starting in the antenatal priode);

2) the differentiated nature of preventive measures;

3) mass prophylaxis;

4) the scientific nature of prevention;

$5)$ the complexity of preventive measures (participation in the prevention of medical institutions, authorities, public organizations, and the public).

Primary prevention, depending on the nature of the facility, also provides for two strategies: population and individual (for high-risk groups), which often complement each other $[5,9,12,16]$.

With a population strategy, the goal of prevention is achieved by solving the problem of reducing the average risk of disease development (hypercholesterolemia or blood pressure, etc.) by conducting activities that cover the entire population or a large part $[1,4,18,23]$.

An individual strategy solves another problem reducing high risk in people assigned to «risk groups» according to one or another epidemiological criteria (gender, age, exposure to a specific factor, etc.).

Secondary prevention is a complex of medical, social, sanitary-hygienic, psychological and other measures aimed at the early detection and prevention of exacerbations, complications and chronic diseases, disabilities that cause disadaptation of patients in society, reduced working capacity, including disability and premature mortality.

Secondary prophylaxis is applicable only to those diseases that can be identified and treated in the early period of development, which helps prevent the transition of the disease to a more dangerous stage. By early detection of patients on the basis of screening tests (mammography, electrocardiogram, etc.) and their treatment, the main goal of the secondary prevention is achieved - the prevention of undesirable outcomes of diseases (death, disability, chronicity, cancer transition to the invasive stage).

\section{Secondary prevention includes:}

1. Targeted sanitary-hygienic education, including individual and group counseling, training of patients and members of their families with knowledge and skills related to a specific disease or a group of diseases.

2. Conducting medical examinations in order to assess the dynamics of the health state, the development of diseases to determine and conduct appropriate recreational and therapeutic measures.

3. Conducting preventive treatment courses and targeted rehabilitation, including therapeutic nutrition, physiotherapy exercises, medical massage and other therapeutic and prophylactic methods of rehabilitation, spa treatment.

4. Conducting medical and psychological adaptation to changing situations in a state of health, forming the correct perception and attitude to the changed capabilities and needs of the body.

5. Carrying out activities of the state, economic, medical and social nature, aimed at reducing the level of influence of modifiable risk factors, maintaining residual disability and the ability to adapt in the social environment, creating conditions for optimal maintenance of the vital activity of patients.

The effectiveness of secondary prevention is determined by a number of circumstances:

1. How often does the disease occur in the population in the preclinical stage?

2. Is the length of the period between the appearance of the first signs and the development of a pronounced disease known?

3. Does the diagnostic test have a high sensitivity and specificity for this disease and is it simple, inexpensive, safe and acceptable?

4. Does clinical medicine have adequate medical means for diagnosing this disease, effective, safe and affordable methods of treatment?

5. Is the necessary medical equipment available?

Tertiary prevention - rehabilitation (synonymous with health restoration) - a set of medical, psychological, pedagogical, social measures aimed at eliminating or compensating for life limitations, lost functions with the aim of the most complete restoration of social and professional status, prevention of relapse and chronic disease.

The goal of tertiary prevention is to slow down the development of complications in case of an already existing disease. Its task is to prevent physical insufficiency and disability, to minimize the suffering caused by the loss of full health, and to help patients in adaptation to incurable conditions. In many cases, in clinical medicine, it is difficult to distinguish between tertiary prophylaxis, treatment and rehabilitation.

\section{Tertiary prevention includes:}

1. Teaching patients and their families the knowledge and skills associated with a particular disease or group of diseases.

2. Clinical examination of patients with chronic diseases and persons with disabilities, including clinical medical examinations with the aim of assessing the dynamics of the state of health and the course of diseases, the implementation of permanent monitoring of them and adequate medical and rehabilitation measures.

3. Conducting medical and psychological adaptation to changing situations in a state of health, forming the correct perception and attitude towards the changed capabilities and needs of the body.

4. Carrying out activities of the state, economic, medical and social nature, aimed at reducing the level of influence of modifiable risk factors.

5. Preservation of residual disability and the possibility of adaptation in social delirium. 
6. Creation of conditions for optimal life support for sick and disabled people (for example, the production of medical nutrition, the implementation of architectural and planning decisions, the creation of appropriate conditions for people with disabilities, etc.).

\section{Types of medical preventive measures:}

-preventive counseling of individuals - health education;

-preventive counseling of population groups - health education;

-preventive medical examinations in order to identify early forms of diseases and risk factors and conduct recreational activities;

-immunization; vaccine prophylaxis;

-clinical examination - medical observation and rehabilitation;

- preventive health-improving measures-occupations with various types of physical culture, sanatorium-resort rehabilitation, physiotherapeutic medical measures, massage, etc.

One of the most important problems facing the practical healthcare in strengthening preventive activities, improving its quality, effectiveness and efficiency is the development of new ones and adaptation to modern requirements and working conditions of modern organizational, information and preventive technologies $[3,6,15,16,20]$.

\section{Quality criteria for preventive care}

Availability and accessibility of the required type of preventive medical services. The criterion is the list and completeness of preventive medical services of the institution (unit, specialist, etc.).

Adequacy of measures, technologies and resources used to the goals of health promotion and prevention. The criterion is the conformity of preventive measures, services, technologies and resources used to the goals of health promotion and prevention in the activities of a medical institution (unit, specialists, etc.) [10,17, 21,24].

Continuity and succession of the process of patients' healing in the healthcare system. The criterion is a model of preventive activity of a medical institution that provides interaction and coordination.

The effectiveness and power of the applied preventive medical intervention on improving the health indicators of groups of people and the population as a whole based on scientific evidence. The criterion is the introduction (application) of evidence-based preventive medical methods, approaches, technologies $[2,5,10,19]$.

The effectiveness of preventive medical intervention in relation to improving the health indicators of certain groups of individuals and the general population in practice. The criterion is the dynamics of health indicators when applying effective methods of prevention in practical conditions.

The effectiveness of the applied preventive medical intervention in relation to the selected criterion. The criterion is the compliance of the result of medical preventive care with the chosen criterion of medical, social, economic efficiency.

The ability to meet the needs of patients, the population and correspond to the real possibilities of ISSN 1727-4338 https://www.bsmu.edu.ua implementation. The criterion is the conformity of forms, methods, technologies, accessibility and other characteristics of preventive medical care, needs, patient attitudes and the general population $[9,18,22,25]$.

\section{Conclusion}

Today, scientists and practitioners have proven that individual preventive measures can affect a limited number of problem factors. It is advisable to organize preventive work only in the form of separate, unrelated activities when the causes of the problem are superficial, not related to the worldview and lifestyle of the target group, and their elimination does not require significant changes in the social environment.

\section{Список літератури}

1. Амлаев К, Дахкильгова Х. Грамотность в вопросах здоровья: понятие, классификации, методы оценки. Врач. 2018;6:83-7. doi: https://doi.org/10.29296/25877305-2018-06-19

2. Богдан ИВ, Гурылина МВ, Чистякова ДП. Здоровый образ жизни: отношение населения и приоритетные направления. Проблемы социальной гигиены, здравоохранения и истории медицины. 2019;27(4):374-8. doi: 10.32687/0869-866X-201927-4-374-378

3. Бойцов СА, Ипатов ПВ, Калинина АМ. Профилактика хронических неинфекционных заболеваний в системе первичной медико-санитарной помощи: совершенствование диспансеризации населения. Заместитель главного врача. $2013 ; 5: 18-25$

4. Бойцов СА, Вылегжанин СВ. Профилактика неинфекционных заболеваний в практике участкового терапевта: содержание, проблемы, пути решения и перспективы. Терапевтический архив. 2015;87(1):4-9. doi: 10.17116/terarkh20158714-9

5. Валиев АШ, Шарафутдинова НХ, Галикеева АШ, Валиев ИР. Особенности профилактической деятельности медицинских организаций различной организационноправовой направленности. Уральский медицинский журнал. 2019;2:121-5. doi: 10.25694/URMJ.2019.02.36

6. Вялков АИ, редактор. Медицинская профилактика. Современные технологии. Руководство. Москва: ГЭОТАРМедиа; 2009. 232 с.

7. Гуревич КГ, Зорин КВ. Педагогические новации и этические аспекты в преподавании вопросов первичной профилактики инфекционных болезней. Инфекционные болезни: новости, мнения, обучение. 2018;7(1):40-5.

8. Жиляева ЕП, Нечаев ВС, Ефремов ДВ. Роль врача общей практики в пропаганде здорового образа жизни. Проблемы социальной гигиены, здравоохранения и истории медицины. 2010;1:47-9.

9. Задворная ОЛ, Борисов КН. Развитие стратегий профилактики неинфекционных заболеваний. Медицинские технологии. Оценка и выбор. 2019;35(1):43-9. doi: https://doi. org/10.31556/2219-0678.2019.35.1.043-049

10. Зорин КВ. Медико-социальные и этические аспекты деятельности врача по профилактике заболеваний в медицинском вузе. Медицинское образование и профессиональное развитие. 2019;10(2):114-20. doi: $10.24411 / 2220-8453-2019-12007$

11. Калининская АА, Сон ИМ. Организационные формы профилактической работы с населением. Проблемы социальной гигиены, здравоохранения и истории медицины. 2019;27(3):323-7. doi: 10.32687/0869-866X-2019-27-3-323-327

12. Кобякова ОС, Деев ИА, Куликов ЕС, Старовойтова ЕА, Малых Клінічна та експериментальна патологія. 2020. Т.19, №1(71) 
РД, Балаганская МА, и др. Хронические неинфекционные заболевания: эффекты сочетанного влияния факторов риска. Профилактическая медицина. 2019;22(2):45-50. doi: 10.17116/ profmed20192202145

13. Концевая АВ, Сапунова ИД, Панов СА, Драпкина ОМ. Использование ценовой политики в первичной профилактике хронических неинфекционных заболеваний: налоги на сахаросодержащие напитки. Профилактическая медицина. 2019;22(5):16-22. doi: 10.17116/profmed20192205116

14. Крутько ВН, Донцов ВИ. Здоровьесбережение как важнейший раздел профилактической медицины (обзор). Главврач. 2016;5:48-58.

15. Лупарев ЕБ. Административно-правовые споры в сфере медицинской деятельности. Медицинское право. 2019;4:1822.

16. Маркова АИ, Флорес МА. Отношение к здоровью в современной семье. Проблемы социальной гигиены, здавоохранения и истории медицины. 2019;27(3):237-42. doi: 10.32687/0869-866Х-2019-27-3-237-242

17. Масленникова ГЯ, Оганов РГ.Профилактиканеинфекционных заболеваний как возможность увеличения ожидаемой продолжительности жизни и здорового долголетия. Кардиоваскулярная терапия и профилактика. 2019;18(2):5-12. doi: https://doi.org/10.15829/1728-8800-2019-2-5-12

18. Морозов МА. Здоровый человек и его окружение Здоровьесберегающие технологии: учеб. пособ. СанктПетербург: Лань; 2016. 372 с.

19. Савченко ЕД, Соболева НП. Анализ организационной деятельности центров медицинской профилактики в оказании профилактической помощи населению. Профилактическая медицина. 2017;20(6):5-13. doi: 10.17116/profmed20172065-13

20. Солодовников ЮЛ. Основы профилактики: учеб. пособ. Санкт-Петербург: Лань; 2017. 292 с.

21. Стародубов ВИ, Сон ИМ, Сененко АШ, Короткова АВ, Леонов $\mathrm{CA}$, Цешковский МC, и др. Общественное здравоохранение и формирование единого профилактического пространства. Менеджер здравоохранения. 2016;4:6-13.

22. Стрельников АА, Обрезан АГ, Шайдаков ЕВ. Скрининг и профилактика актуальных заболеваний: руководство для врачей. Санкт-Петербург: СпецЛит; 2012. 535 с.

23. Шевцова НН, Оганов РГ, Суслонова НВ. Семейная медицина - оптимальный подход к профилактике сердечно-сосудистых и других неинфекционных заболеваний. Кардиоваскулярная терапия и профилактика. 2015;14(5):4-7. doi: https://doi. org/10.15829/1728-8800-2015-5-4-7

24. Таранцова АВ. Донозологическая диагностика и профилактика хронических неинфекционных социальнозначимых заболеваний. Москва: Панорама; 2015. 96 с.

25. Усова ЕВ, Попович МВ, Маньшина АВ, Зиновьева ВА, Глазунов ИС, Старовойтов МЛ. Аспекты оценки динамики информированности медицинских специалистов в вопросах профилактики неинфекционных заболеваний. Профилактическая медицина. 2019;22(5):27-31. doi: 10.17116/ profmed20192205127

\section{References}

1. Amlaev K, Dakhkilgova Kh. Gramotnost' v voprosakh zdorov'ya: ponyatie, klassifikatsii, metody otsenki [Health literacy matters: concept, classification, methods of assessment]. Vrach. 2018;6:83-7. doi: https://doi.org/10.29296/25877305-2018-06-19 (in Russian)

2. Bogdan IV, Gurylina MV, Chistiakova DP. Zdorovyy obraz zhizni: otnoshenie naseleniya i prioritetnye napravleniya [The healthy life-style: attitude of population and priority directions]. Problemy sotsial'noy gigieny, zdravookhraneniya $\mathrm{i}$ istorii meditsiny. 2019;27(4):374-8. doi: 10.32687/0869-866X-201927-4-374-378 (in Russian)

3. Boytsov SA, Ipatov PV, Kalinina AM. Profilaktika khronicheskikh neinfektsionnykh zabolevaniy $\mathrm{V}$ sisteme pervichnoy medikosanitarnoy pomoshchi: sovershenstvovanie dispanserizatsii naseleniya [Prevention of chronic noncommunicable diseases in the primary health care system: improving the medical examination of the population]. Zamestitel' glavnogo vracha. 2013;5:18-25. (in Russian)

4. Boitsov SA, Vylegzhanin SV. Profilaktika neinfektsionnykh zabolevaniy $\mathrm{v}$ praktike uchastkovogo terapevta: soderzhanie, problemy, puti resheniya i perspektivy [Prevention of noncommunicable diseases in a local therapist's practice: Content, problems, solution ways, and prospects]. Therapeutic archive. 2015;87(1):4-9. doi: 10.17116/terarkh20158714-9 (in Russian)

5. Valiev ASh, Sharafutdinova NKh, Galikeeva AS, Valiev IR Osobennosti profilakticheskoy deyatel'nosti meditsinskikh organizatsiy razlichnoy organizatsionno-pravovoy napravlennosti [Peculiar properties of prophylactic medical care in organizations of various organizational and legal orientation]. Ural Medical Journal. 2019;2:121-5. doi: 10.25694/URMJ.2019.02.36 (in Russian)

6. Vyalkov AI, redaktor. Meditsinskaya profilaktika. Sovremennye tekhnologii. Rukovodstvo [Medical prophylaxis. Modern technologies. Guide]. Moscow: GEOTAR-Media; 2009. 232 p. (in Russian)

7. Gurevich KG, Zorin KV. Pedagogicheskie novatsii i eticheskie aspekty $\mathrm{V}$ prepodavanii voprosov pervichnoy profilaktiki infektsionnykh bolezney [Pedagogical innovations and ethical aspects in the teaching of primary prevention of infectious diseases]. Infectious Diseases: News, Opinions, Training. 2018;7(1):40-5. (in Russian)

8. Zhilyaeva EP, Nechaev VS, Efremov DV. Rol' vracha obshchey praktiki $\mathrm{v}$ propagande zdorovogo obraza zhizni [The role of a general practitioner in the popularization of healthy lifestyle]. Problemy sotsial'noy gigieny, zdravookhraneniya i istorii meditsiny. 2010;1:47-9. (in Russian)

9. Zadvornaya OL, Borisov KN. Razvitie strategiy profilaktik neinfektsionnykh zabolevaniy [Development of Prevention Strategies for Non-Communicable Diseases]. Medical Technologies. Assessment and Choice. 2019;35(1):43-9. doi: https://doi.org/10.31556/2219-0678.2019.35.1.043-049 (in Russian)

10. Zorin KV. Mediko-sotsial'nye i eticheskie aspekty deyatel'nost vracha po profilaktike zabolevaniy $\mathrm{V}$ meditsinskom vuze [Medical, social and ethical aspects of the doctor's activities on the prevention of diseases in the medical institute]. Medical Education and Professional Development. 2019;10(2):114-20. doi: 10.24411/2220-8453-2019-12007 (in Russian)

11. Kalininskaia AA, Son IM. Organizatsionnye formy profilakticheskoy raboty s naseleniem [The organizational forms of preventive activities in population]. Problemy sotsial'noy gigieny, zdravookhraneniya i istorii meditsiny. 2019;27(3):323-7. doi: 10.32687/0869-866X-2019-27-3-323-327 (in Russian)

12. Kobyakova OS, Deev IA, Kulikov ES, Starovoytova EA, Malykh RD, Balaganskaya MA, i dr. Khronicheskie neinfektsionnye zabolevaniya: effekty sochetannogo vliyaniya faktorov riska [Chronic noncommunicable diseases: combined effects of risk factors]. Profilakticheskaya meditsina. 2019;22(2):45-50. doi: 10.17116/profmed20192202145 (in Russian)

13. Kontsevaya AV, Sapunova ID, Panov SA, Drapkina OM. Ispol'zovanie tsenovoy politiki $\mathrm{V}$ pervichnoy profilaktike khronicheskikh neinfektsionnykh zabolevaniy: nalogi na sakharosoderzhashchie napitki [The use of pricing policy in the 
primary prevention of chronic noncommunicable diseases: taxes on sugary drinks]. Profilakticheskaya meditsina 2019;22(5):1622. doi: 10.17116/profmed20192205116 (in Russian)

14. Krut'ko VN. Dontsov VI. Zdorov'esberezhenie kak vazhneyshiy razdel profilakticheskoy meditsiny (obzor) [Health-saving as important area of preventive medicine (review)]. Glavvrach. 2016;5:48-58. (in Russian)

15. Luparev EB. Administrativno-pravovye spory $\mathrm{V}$ sfere meditsinskoy deyatel'nosti [Administrative and Legal Disputes in the Area of Medical Activity . Meditsinskoe pravo. 2019;4:18-22. (in Russian)

16. Markova AI, Flores MA. Otnoshenie k zdorov'yu v sovremennoy sem'e [The attitude to health in modern family]. Problemy sotsial'noy gigieny, zdravookhraneniya i istorii meditsiny. 2019;27(3):237-42. doi: 10.32687/0869-866X-2019-27-3-237242 (in Russian)

17. Maslennikova GY, Oganov RG. Profilaktika neinfektsionnykh zabolevaniy kak vozmozhnost' uvelicheniya ozhidaemoy prodolzhitel'nosti zhizni i zdorovogo dolgoletiya [Prevention of noncommunicable diseases as an opportunity to increase life expectancy and healthy longevity ]. Cardiovascular Therapy and Prevention. 2019;18(2):5-12. doi: https://doi.org/10.15829/17288800-2019-2-5-12 (in Russian)

18. Morozov MA. Zdorovyy chelovek i ego okruzhenie. Zdorov'esberegayushchie tekhnologii [Healthy person and his environment. Health Saving Technology]: ucheb. posob. SanktPeterburg: Lan'; 2016. 372 p. (in Russian)

19. SavchenkoED, SobolevaNP.Analizorganizatsionnoy deyatel'nosti tsentrov meditsinskoy profilaktiki $\mathrm{v}$ okazanii profilakticheskoy pomoshchi naseleniyu [Analysis of the organizational activities of preventive medicine centers in providing preventive care]. Profilakticheskaya meditsina. 2017;20(6):5-13. doi: 10.17116/ profmed20172065-13 (in Russian)

20. Solodovnikov YuL. Osnovy profilaktiki [Prevention Basics]: ucheb. posob. Sankt-Peterburg: Lan'; 2017. 292 p. (in Russian)

21. Starodubov VI, Son IA, Senenko AS, Korotkova AV, Leonov SA, Cheshkovsky MS, i dr. Obshchestvennoe zdravookhranenie i formirovanie edinogo profilakticheskogo prostranstva [Public Health and Formation of the Uniform Preventive Space]. Menedzher zdravookhraneniya. 2016;4:6-13. (in Russian)

22. Strel'nikov AA, Obrezan AG, Shaydakov EV. Skrining i profilaktika aktual'nykh zabolevaniy: rukovodstvo dlya vrachey [Screening and Prevention of Topical Diseases: A Guide for Physicians]. Sankt-Peterburg: SpetsLit; 2012. 535 p. (in Russian)

23. Suslonova NV, Oganov RG, Shevtsova NN. Semeynaya meditsina - optimal'nyy podkhod k profilaktike serdechno-sosudistykh i drugikh neinfektsionnykh zabolevaniy [Family medicine - the optimal approach to prevention of cardiovascular and other noncommunicable diseases]. Cardiovascular Therapy and Prevention. 2015;14(5):4-7. doi: https://doi.org/10.15829/1728-8800-2015-54-7 (in Russian)

24. Tarantsova AV. Donozologicheskaya diagnostika i profilaktika khronicheskikh neinfektsionnykh sotsial'no-znachimykh zabolevaniy [Pre-nosological diagnosis and prevention of chronic non-infectious socially significant diseases]. Moscow: Panorama; 2015. 96 p. (in Russian)

25. Oussova EV, Popovich MV, Manshina AV, Zinovyeva VA, Glazunov IS, Starovoytov ML. Aspekty otsenki dinamiki informirovannosti meditsinskikh spetsialistov $\mathrm{V}$ voprosakh profilaktiki neinfektsionnykh zabolevaniy [Aspects of assessing the dynamics of awareness about the prevention of noncommunicable diseases among medical professionals]. Profilakticheskaya meditsina. 2019;22(5):27-31. doi: 10.17116/ profmed20192205127 (in Russian)

\section{Відомості про авторів:}

Бідучак А.С. - к.мед.н., доцент кафедри соціальної медицини та організації охорони здоров’я ВДНЗ України «Буковинський державний медичний університет», м. Чернівці.

Грицюк М.I. - д.мед.н, доцент кафедри соціальної медицини та організації охорони здоров’я ВДНЗ України «Буковинський державний медичний університет», м. Чернівці.

ДоманчукT.I. - асистент кафедри соціальної медицини та організації охорони здоров'я ВДНЗ України «Буковинський державний медичний університет», м. Чернівці.

\section{Сведения об авторах:}

Бидучак А.С. - к.мед.н., доцент кафедры социальной медицины и организации здравоохранения Высшего государственного учебного заведения «Буковинский государственный медицинский університет», г. Черновцы. Грицюк М.И. - д.мед.н, доцент кафедры социальной медицины и организации здравоохранения Высшего государственного учебного заведения «Буковинский государственный медицинский університет», г. Черновцы. Доманчук Т.И. - ассистент кафедры социальной медицины и организации здравоохранения Высшего государственного учебного заведения «Буковинский государственный медицинский університет», г. Черновцы.

\section{Information about authors:}

Biduchak A.S. - Ph.D, assistant professor of the Department of Social Medicine and Public Health of the Higher State Educational Establishment of Ukraine «Bukovinian State Medical University», Chernivtsi.

Grytsyuk M.I. - Ph.D, assistant Professor of the Department of Social Medicine and Public Health of the Higher State Educational Establishment of Ukraine «Bukovinian State Medical University», Chernivtsi.

Domanchuk T.I. - assistant of the Department of Social Medicine and Public Health of the Higher State Educational Establishment of Ukraine «Bukovinian State Medical University», Chernivtsi.

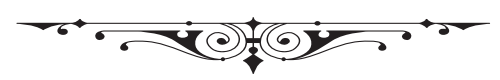

